\title{
3 Research Square

\section{Comorbidities of COVID-19 Patients With Low Cycle Threshold (Ct) Value of Nucleocapsid (N) Gene: An Application to Cluster-Based Logistic Model.}

SUJAN RUDRA ( $\nabla$ sujan1rudra@gmail.com )

University of Chittagong https://orcid.org/0000-0001-9160-9169

SHUVA DAS

Chittagong Medical College

MD. EHSANUL HOQUE

Chittagong Medical College

ABUL KALAM

Chittagong Medical College

MOHAMMAD ARIFUR RAHMAN

Chittagong Medical College

SWAGATA NANDY SHIZUKA

Chittagong Medical College

TAZRINA RAHMAN

Chittagong Medical College

Research

Keywords: Comorbidity, COVID-19, rRT-PCR, Ct value; N gene, Cluster-based logistic regression

Posted Date: January 21st, 2021

DOI: https://doi.org/10.21203/rs.3.rs-147576/v2

License: (c) (i) This work is licensed under a Creative Commons Attribution 4.0 International License.

Read Full License 


\section{Abstract}

Background: Coronavirus disease 2019 (COVID-19) is a health crisis throughout the world. The widely used Real-time Reverse Transcriptase Polymerase Chain Reaction (rRT-PCR) method is most capable of describing the patient's condition. Comorbidities can make patients more critical.

Methods: In this study, we shed light on the low cycle threshold (Ct) value of the $\mathrm{N}$ gene in the rRT-PCR test of the COVID-19 patients who had comorbidities, cure rate, and the needfulness of ICU (Intensive Care Unit) management. We had conducted the research in the Molecular Biology Laboratory of Chittagong Medical College between May and August 2020, then took the telephone interview with 300 positive patients who fulfilled the study criteria. We applied cluster-based logistic regression to analyze the data.

Results: Low Ct value of the $\mathrm{N}$ gene found 1.324 times more in Type $2 \mathrm{DM}$ patients and 1.871 times higher in hypertensive patients, and hospitalized patients are 2.480 times more vulnerable to shift in ICU.

Conclusions: While infection with Severe Acute Respiratory Syndrome Coronavirus 2 (SARS-CoV-2) frequently causes severe diseases, suspected cases with comorbid conditions should go through the rRTPCR as early as possible.

\section{Background}

In December 2019, SARS-CoV-2 presented for the reason of Coronavirus Disease 19 (COVID-19) pandemic $[1,2]$. The International Committee on Taxonomy of Viruses (ICTV) declared this virus as the novel coronavirus in January 2020. ICTV named this virus because of their 9-12 nm long surface spikes that resemble a corona (equal to the crown in Latin). Coronavirus is an enveloped virus. They are singlestranded and belong to a positive-sense RNA genome. It is the 7th coronavirus and 3rd zoonotic human coronavirus $(\mathrm{HCoV})$ of the century. It is posing threats to international health too.

It has now affected almost all countries and has led to over 25 million confirmed cases. Globally 870497 deaths have occurred till August 2020. There are also asymptomatic or mildly symptomatic cases [1-4], but enormous patients progress to severe COVID-19 with high mortality rates. By July 2020, over 600,000 deaths recorded worldwide. Presently seven CoVs (including SARS-CoV-2) can cause human respiratory diseases to date, only Severe Acute Respiratory Syndrome Coronavirus (SARS-CoV), Middle East Respiratory Syndrome Coronavirus (MERS-CoV), and SARS-CoV-2 have caused a large outbreak with high mortality. They can harm almost all systems: respiratory, gastrointestinal, cardiovascular, and nervous systems with variable severity [5] of our body.

High viral loads in severe COVID-19 show higher viral replication and pathology [6], which results in multiorgan failure [7]. But it is not always true, as some studies found asymptomatic individuals can have high viral loads [8]. In this research, we explored the association of low $\mathrm{Ct}$ value of viral $\mathrm{N}$ gene with the comorbidities in both home and hospital cluster. We also tried to find the clinical outcomes of the corresponding patient in this research. 


\section{Methods}

The molecular biology laboratory of Chittagong Medical College conducted this cross-sectional study from May 2020 to August 2020. Reverse Transcriptase-Polymerase Chain Reaction was done in the QuantStudio 5 Real-Time PCR instrument (96-Well 0.2 ml Block) by Sansure Biotech Novel Coronavirus Nucleic Acid Diagnostic Kit.

We included rRT-PCR confirmed COVID-19 patients who had three days of symptoms. Interviewers collected the following parameters of the corresponding patients over the phone: presence of symptoms, days of illness, contact with the symptomatic patient, types of personal protective equipment used, traveling history, oxygen requirement, hospital admission history, ICU support, co-morbidities, $\mathrm{pH}, \mathrm{HCO}$, Oxygen saturation, Arterial $\mathrm{CO} 2$, Arterial 02, other baseline investigations, and treatment sheet.

The WHO website has provided several Real-time RT-PCR protocols for detecting SARS-CoV-2 in different countries [9]. Three fluorescent signals from FAM, ROX, and CY 5 channels detected the viral copy DNA (cDNA). We selected the nucleocapsid protein gene $\mathrm{N}$ and the RNA-dependent RNA polymerase gene (RdRP) [also reported as Open Reading Frame 1ab (ORF1ab)] [10]. Internal control helped to check for biases of the total procedure. We used a positive control such as plasmids containing the complete SARS-CoV-2 N gene [11] in our study.

Here, the Ct values of the targeted genes express the RNA virus. We listed 300 patients from 436 COVID19 patients in our study. We got relevant history properly from those 300 patients. We filled up the questionnaires by clinical characteristics and treatment of the patients. We took written informed consent from the patients or by next-of-kin. This study got approval from local regulatory authorities.

We used descriptive statistics, logistics regression, and cluster-based logistics regression to explain the $\mathrm{N}$ gene-related factors.

\section{Results}

We classified patients' conditions into three categories: ICU support with non-invasive procedures, ICU support with mechanical ventilation, and those who need none of these. The patients who had a low Ct value (15.00-30.00) of the nucleocapsid gene needed more ICU support (13\%) than the patients who had a high Ct value (30.01-40.00). With the ORF1ab gene, it was different. Here, patients with a high Ct value used 16.3\% ICU (both Non-invasive and Mechanical ventilation) facilities than the patients with low Ct value. In our study, elderly patients ( $\geq 60$ years age) belonging low (15.00-30.00) Ct value of $\mathrm{N}$ gene needed the highest (34.6\%) ICU support. Children did not require any intensive care support. Only 40-59 years of age group patients needed mechanical ventilation (8.3\%). 
From Figure 1, we found the highest number (79) of cases who were suffering from hypertension (63.7\%) had low Ct value (15.00-30.00) of $\mathrm{N}$ gene, and those patients needed more intensive care support for deteriorating their health conditions than the patients of high $\mathrm{Ct}$ value (30.01-40.00). Diabetic patients were in the second $(48.4 \%)$ position. The patients who had low risk were suffering from CVD $(2.4 \%)$ with a low $\mathrm{Ct}$ value of the $\mathrm{N}$ gene. From those comorbid conditions, hypertension and type2 DM are significant with $\mathrm{N}$ gene values by chi-square test.

Table 1: $\mathrm{N}$ gene range with cluster-based comorbid conditions.

\begin{tabular}{|llllll|}
\hline Comorbidity & Categories & \multicolumn{2}{l}{ Low Ct } & $(15.00-30.00)$ of N gene & \multicolumn{2}{l|}{ High Ct (30.01-40.00) of N gene } \\
\cline { 3 - 6 } & & Home & Hospital & Home & Hospital \\
\hline \multirow{2}{*}{ Type2 DM } & No & $29.00 \%$ & $17.00 \%$ & $25.00 \%$ & $9.00 \%$ \\
\cline { 2 - 6 } & Yes & $3.00 \%$ & $11.00 \%$ & $2.00 \%$ & $4.00 \%$ \\
\hline \multirow{2}{*}{ Hypertention } & No & $25.00 \%$ & $16.00 \%$ & $25.70 \%$ & $7.00 \%$ \\
\cline { 2 - 6 } & Yes & $7.00 \%$ & $12.00 \%$ & $1.30 \%$ & $6.00 \%$ \\
\hline
\end{tabular}

Table 1 represented that home treatment cured the patients who were not suffering from type 2 DM (29\%) and hypertension (25\%), though they had a low Ct value of the $\mathrm{N}$ gene. But diabetic and hypertensive patients needed more (11.00\% and $12.00 \%$, respectively) hospital treatment for those who had a low $\mathrm{Ct}$ value of the $\mathrm{N}$ gene. Having a high $\mathrm{Ct}$ value of the $\mathrm{N}$ gene, non-diabetic and normotensive patients cured more in-home treatment $(25.00 \%$ and $25.70 \%$, respectively).

Table 2: Cluster-based Logistic model: Effect of Comorbidities on low Ct value 


\begin{tabular}{|c|c|c|c|c|c|c|c|}
\hline \multicolumn{8}{|c|}{ Logistics Regression model for general data } \\
\hline \multirow[t]{2}{*}{ Comorbidities } & \multirow[t]{2}{*}{ Categories } & \multirow[t]{2}{*}{ B } & \multirow[t]{2}{*}{ S.E. } & \multirow[t]{2}{*}{ Sig. } & \multirow[t]{2}{*}{$\operatorname{Exp}(B)$} & \multicolumn{2}{|l|}{$95 \%$ C.I } \\
\hline & & & & & & Lower & Upper \\
\hline \multirow[t]{2}{*}{ Type 2 DM } & Yes & 0.280 & 0.337 & 0.046 & 1.324 & 0.683 & 2.565 \\
\hline & No & -- & - & - & 1.000 & - & - \\
\hline \multirow[t]{2}{*}{ Hypertention } & Yes & 0.626 & 0.308 & 0.042 & 1.871 & 1.024 & 3.419 \\
\hline & No & -- & - & - & 1.000 & -- & - \\
\hline Constant & & -1.105 & 0.315 & 0.000 & 0.331 & & \\
\hline \multicolumn{8}{|c|}{ Cluster-based Logistics Regression (Home Cluster) } \\
\hline \multirow[t]{2}{*}{ Variable } & Categories & B & S.E. & Sig. & $\operatorname{Exp}(B)$ & $95 \%$ C.I & \\
\hline & & & & & & Lower & Upper \\
\hline \multirow[t]{2}{*}{ Type 2 DM } & Yes & 0.175 & 0.603 & 0.071 & 1.192 & 0.365 & 3.888 \\
\hline & No & - & - & - & 1.000 & - & - \\
\hline \multirow[t]{2}{*}{ Hypertention } & Yes & -1.718 & 0.582 & 0.003 & 0.179 & 0.057 & 0.562 \\
\hline & No & - & - & - & 1.000 & - & - \\
\hline Constant & & 0.016 & 0.166 & 0.923 & 1.016 & & \\
\hline \multicolumn{8}{|c|}{ Cluster-based Logistics Regression (Hospital Cluster) } \\
\hline \multirow[t]{2}{*}{ Variable } & Categories & B & S.E. & Sig. & $\operatorname{Exp}(B)$ & $95 \%$ C.I & \\
\hline & & & & & & Lower & Upper \\
\hline \multirow[t]{2}{*}{ Type 2 DM } & Yes & -0.503 & 0.448 & 0.262 & 0.605 & 0.251 & 1.456 \\
\hline & No & - & - & - & 1.000 & - & - \\
\hline \multirow[t]{2}{*}{ Hypertention } & Yes & 0.319 & 0.425 & 0.045 & 1.375 & 0.598 & 3.162 \\
\hline & No & - & - & - & 1.000 & - & - \\
\hline Constant & & -0.733 & 0.273 & 0.007 & 0.480 & & \\
\hline
\end{tabular}

Building logistics regression and cluster-based logistic regression, we defined the $\mathrm{N}$ gene range (low and high) as a dependent variable and significant comorbidities as independent variables. In the logistics regression model for general data, type 2 diabetic patients had a 1.324 times more low Ct value of the $\mathrm{N}$ gene. Similarly, in the home cluster, it was 1.192 times higher with $\mathrm{Cl}(0.365,3.888)$. But in the hospital cluster, the scenario was reversed (0.605), which was not significant. Hypertensive patients possessed 
1.871 times significantly $(p=0.042)$ more low $\mathrm{Ct}$ value of the $\mathrm{N}$ gene in the full dataset. Similarly, it was 1.375 times more in the hospital cluster. But, the home cluster represented that hypertensive patients had significantly (0.179 times with p-value 0.003$)$ low Ct value of $\mathrm{N}$ gene.

Table 3: ICU support according to $\mathrm{Ct}$ value range of $\mathrm{N}$ gene.

\begin{tabular}{|c|c|c|c|c|c|c|}
\hline \multirow[t]{2}{*}{ ICU } & \multicolumn{2}{|c|}{$\begin{array}{l}\text { Low Ct (15.00-30.00) of } \mathrm{N} \\
\text { gene }\end{array}$} & \multicolumn{2}{|c|}{$\begin{array}{l}\text { High Ct (30.01-40.00) of } \mathrm{N} \\
\text { gene }\end{array}$} & \multicolumn{2}{|c|}{ ICU support type } \\
\hline & Home & Hospital & Home & Hospital & $\begin{array}{l}\text { Non- } \\
\text { invasive }\end{array}$ & $\begin{array}{l}\text { Mechanical } \\
\text { ventilation }\end{array}$ \\
\hline No & $30.00 \%$ & $17.00 \%$ & $25.00 \%$ & $5.00 \%$ & & \\
\hline Yes & $2.00 \%$ & $11.00 \%$ & $2.00 \%$ & $8.00 \%$ & $20.00 \%$ & $3.00 \%$ \\
\hline
\end{tabular}

From table $3,23.00 \%$ of patients needed ICU, where $20.00 \%$ used non-invasive methods, and $3.00 \%$ went for mechanical ventilation. Besides, $11.00 \%$ of hospitalized patients needed ICU, who had a low Ct value of the $\mathrm{N}$ gene. On the alternative, $8.00 \%$ of hospitalized patients needed ICU, who had a high Ct value of the $\mathrm{N}$ gene.

Table 4: Cluster-based Logistic model: effect of N Gene on ICU support. 


\begin{tabular}{|c|c|c|c|c|c|c|c|}
\hline \multicolumn{8}{|c|}{ Logistics Regression model for general data } \\
\hline \multirow[t]{2}{*}{ Target } & \multirow[t]{2}{*}{ Categories } & \multirow[t]{2}{*}{$\mathrm{B}$} & \multirow[t]{2}{*}{ S.E. } & \multirow[t]{2}{*}{ Sig. } & \multirow[t]{2}{*}{$\operatorname{Exp}(B)$} & \multicolumn{2}{|l|}{$95 \%$ C.I } \\
\hline & & & & & & Lower & Upper \\
\hline \multirow[t]{2}{*}{ N Gene } & Low & -0.187 & 0.278 & 0.052 & 0.830 & 0.481 & 1.430 \\
\hline & High & - & - & - & 1.000 & - & - \\
\hline Constant & & -1.099 & 0.211 & 0.000 & 0.333 & - & - \\
\hline \multicolumn{8}{|c|}{ Cluster-based Logistics Regression (Home Cluster) } \\
\hline & \multirow[t]{2}{*}{ Categories } & \multirow[t]{2}{*}{$\mathrm{B}$} & \multirow[t]{2}{*}{ S.E. } & \multirow[t]{2}{*}{ Sig. } & \multirow[t]{2}{*}{$\operatorname{Exp}(B)$} & \multicolumn{2}{|l|}{$95 \%$ C.I } \\
\hline & & & & & & Lower & Upper \\
\hline \multirow[t]{2}{*}{ N Gene } & Low & -0.182 & 0.598 & 0.076 & 0.833 & 0.258 & 2.691 \\
\hline & High & - & - & - & 1.000 & - & - \\
\hline Constant & & -2.526 & 0.424 & 0.000 & 0.080 & -- & -- \\
\hline \multicolumn{8}{|c|}{ Cluster-based Logistics Regression (Hospital Cluster) } \\
\hline \multirow[b]{2}{*}{ Target } & Categories & $\mathrm{B}$ & S.E. & Sig. & $\operatorname{Exp}(B)$ & \multicolumn{2}{|l|}{$95 \%$ C.I } \\
\hline & & & & & & Lower & Upper \\
\hline \multirow[t]{2}{*}{ N Gene } & Low & -0.905 & 0.398 & 0.023 & 2.480 & 0.882 & 5.026 \\
\hline & High & - & - & - & 1.000 & - & - \\
\hline Constant & & 0.470 & 0.329 & 0.153 & 1.600 & - & -- \\
\hline
\end{tabular}

Building logistics regression and cluster-based logistic regression, we defined the patients' condition into two categories: who needed ICU support and those who did not need any ICU support rolled as a dependent variable. Table 4 represented that ICU patients were 0.17 times lower than those who had a low Ct value (15.00-30.00) of viral $\mathrm{N}$ gene in the rRT-PCR method than the high Ct value (30.01-40.00). But, hospital clusters in the cluster-based logistic regression method, ICU admissions were significantly 2.480 times $(\mathrm{Cl} 0.882,5.026)$ higher than patients having a low $\mathrm{Ct}$ value of the $\mathrm{N}$ gene.

\section{Discussion}

We found that patients with low Ct values were more likely to have Hypertension ( $n=79)$, Type 2 DM ( $n=$ 60), COPD $(n=33)$, Bronchial Asthma $(n=15), \operatorname{CKD}(n=9)$. Decreased oxygenation in the heart and kidney or increased infection may be responsible for this. Another study revealed that SARS-CoV-2 directly infects both the heart and kidney [12]. Renal and cardiovascular complications are common in 
severe COVID-19 [13, 14]. Further studies can evaluate the relationships between the lower level of Ct value of the $\mathrm{N}$ gene and disease severity.

Maximum patients of COVID-19 had mild symptoms [15], but $18 \%-33 \%$ of patients required invasive procedures in ICU, and $20 \%$ of patients died in the hospital in different studies [16-20]. Previous studies reflect that the low $\mathrm{Ct}$ value corresponds with the high viral loads. Our study highlights the low level of the $\mathrm{Ct}$ value of the $\mathrm{N}$ gene detecting SARS-CoV-2 can deteriorate patients' condition.

Viral loads express COVID-19 severity [21] as a prognostic biomarker [22], but there is no harmony across the studies [23, 24]. In our analysis, more patients in ICU had low Ct of $\mathrm{N}$ gene. Magleby et al. [21] also found a similar result. Ct values help to identify patients who are in a risky zone and who need more intensive care. It may also help to select antiviral agents [25].

There were some limitations in our study. First, we analyzed only the Ct value of a single time sample, so we could not assess viral load dynamics overtime. Second, our study population size was small, and the study period was short.

\section{Conclusion}

We pointed the hazardous conditions of the patients depend on the $\mathrm{Ct}$ value range of the $\mathrm{N}$ gene. Even it is worst when there are comorbidities (Type $2 \mathrm{DM}$ and Hypertension). This information is useful for selecting patients for COVID-19 who require special management and follow-up at home or hospital. We pointed the hazardous conditions of the patients depend on the $\mathrm{Ct}$ value range of the $\mathrm{N}$ gene. Even it is worst when there are comorbidities (Type $2 \mathrm{DM}$ and Hypertension). This information is useful for selecting patients for COVID-19 who require precise management and follow-up at home or hospital. These findings also highlight the critical role of viral load. It also suggests that clinicians should follow the $\mathrm{Ct}$ values in identifying patients at high-risk conditions.

\section{Abbreviations}

SARS-CoV-2 = Severe Acute Respiratory Syndrome Coronavirus 2

COVID-19 = Coronavirus disease 2019

$\mathrm{Ct}=$ Cycle Threshold

$\mathrm{N}=$ Nucleocapsid

rRT-PCR = Real-time Reverse Transcriptase Polymerase Chain Reaction

$\mathrm{ICU}=$ Intensive Care Unit

ICTV = International Committee on Taxonomy of Viruses 
CoVs $=$ Coronaviruses

$\mathrm{HCoV}=$ Human Coronaviruses

SARS-CoV = Severe Acute Respiratory Syndrome Coronavirus

MERS-CoV = Middle East Respiratory Syndrome Coronavirus

cDNA = Complementary DNA

RdRP = RNA-dependent RNA polymerase gene

ORF1ab = Open Reading Frame $1 \mathrm{ab}$

DM = Diabetes Mellitus

COPD $=$ Chronic Obstructive Pulmonary Disease

$\mathrm{CKD}=$ Chronic Kidney Disease

$\mathrm{IHD}=$ Ischemic Heart Disease

CVD = Cardio-vascular Disease

$\operatorname{Exp}(B)=$ odds ratio

$\mathrm{Cl}=$ confidence interval

\section{Declarations}

Ethics approval and consent to participate

The study protocol was assessed and approved by the medical ethics committee of the Chittagong Medical College and Hospital, Chattogram.

\section{Consent for publication}

Not applicable

\section{Availability of data and materials}

Upon reasonable request.

\section{Competing interests}

The authors declare no conflict of interest. 


\section{Funding}

Not applicable

\section{Author contributions}

SUJAN RUDRA: Data curation; Statistical analysis

SHUVA DAS: Conceptualization; Roles/Writing - original draft

MD. EHSANUL HOQUE: Supervision

ABUL KALAM: Writing - Review \& editing

MOHAMMAD ARIFUR RAHMAN: Validation; Visualization

SWAGATA NANDY SHIZUKA: Investigation

TAZRINA RAHMAN: Methodology

All the authors have accepted equal responsibility for the entire content of this submitted manuscript and approved submission.

\section{Acknowledgements}

We would like to thanks the editors and referees whose constructive criticism led us to develop the presentation and maintain the quality of the paper. We would also like to thanks the Molecular Biology Laboratory of Chittagong Medical College, Chattogram, to give their almost all opportunity for conducting the research.

\section{References}

[1] Chan JF, Yuan S, Kok KH, To KK, Chu H, Yang J, et al. A familial cluster of pneumonia associated with the 2019 novel coronavirus indicating person-to-person transmission: a study of a family cluster. The Lancet. 2020 Feb 15;395(10223):514-23.

[2] Huang C, Wang Y, Li X, Ren L, Zhao J, Hu Y, et al. Clinical features of patients infected with 2019 novel coronavirus in Wuhan, China. The lancet. 2020 Feb 15;395(10223):497-506.

[3] Chen N, Zhou M, Dong X, Qu J, Gong F, Han Y, et al. Epidemiological and clinical characteristics of 99 cases of 2019 novel coronavirus pneumonia in Wuhan, China: a descriptive study. The Lancet. 2020 Feb 15;395(10223):507-13.

[4] Guan WJ, Ni ZY, Hu Y, Liang WH, Ou CQ, He JX, et al. Clinical characteristics of coronavirus disease 2019 in China. New England journal of medicine. 2020 Apr 30;382(18):1708-20. 
[5] Madjid M, Safavi-Naeini P, Solomon SD, Vardeny O. Potential effects of coronaviruses on the cardiovascular system: a review. JAMA cardiology. 2020 Mar 27.

[6] Mason RJ. Pathogenesis of COVID-19 from a cell biology perspective.

[7] Jose RJ, Manuel A. COVID-19 cytokine storm: the interplay between inflammation and coagulation. The Lancet Respiratory Medicine. 2020 Apr 27.

[8] Tan L, Kang X, Zhang B, Zheng S, Liu B, Yu T, et al. A special case of COVID-19 with long duration of viral shedding for 49 days. medRxiv. 2020 Jan 1.

[9] World Health Organization, Coronavirus disease (COVID-19) technical guidance: Laboratory testing for 2019-nCoV in humans. https://www.who.int/emergencies/diseases/novel-coronavirus2019/technicalguidance/laboratory-guidance,_(2020).

[10] "Laboratory Testing for 2019 Novel Coronavirus (2019-nCoV) in Suspected Human Cases." n.d. Accessed April 14, 2020. https://www.who.int/publications-detail/laboratory-testing-for-2019-novelcoronavirus-in-suspected-human-cases-20200117.

[11] Wu Y, Xu X, Chen Z, Duan J, Hashimoto K, Yang L, et al. Nervous system involvement after infection with COVID-19 and other coronaviruses. Brain, behavior, and immunity. 2020 Mar 30.

[12] Puelles VG, Lütgehetmann M, Lindenmeyer MT, Sperhake JP, Wong MN, Allweiss L, et al. Multiorgan and renal tropism of SARS-CoV-2. New England Journal of Medicine. 2020 May 13.

[13] Shi S, Qin M, Shen B, Cai Y, Liu T, Yang F, et al. Association of cardiac injury with mortality in hospitalized patients with COVID-19 in Wuhan, China. JAMA cardiology. 2020 Mar 25.

[14] Pei G, Zhang Z, Peng J, Liu L, Zhang C, Yu C, et al. Renal involvement and early prognosis in patients with COVID-19 pneumonia. Journal of the American Society of Nephrology. 2020 Jun 1;31(6):1157-65.

[15] Wu Z, McGoogan JM. Characteristics of and important lessons from the coronavirus disease 2019 (COVID-19) outbreak in China: summary of a report of 72314 cases from the Chinese Center for Disease Control and Prevention. Jama. 2020 Apr 7;323(13):1239-42.

[16] Richardson S, Hirsch JS, Narasimhan M, Crawford JM, McGinn T, Davidson KW, et al. Presenting characteristics, comorbidities, and outcomes among 5700 patients hospitalized with COVID-19 in the New York City area. Jama. 2020 Apr 22.

[17] Gold JA. Characteristics and clinical outcomes of adult patients hospitalized with COVID-19Georgia, March 2020. MMWR. Morbidity and mortality weekly report. 2020;69.

[18] Goyal P, Choi JJ, Pinheiro LC, Schenck EJ, Chen R, Jabri A, et al. Clinical characteristics of Covid-19 in New York city. New England Journal of Medicine. 2020 Apr 17. 
[19] Cummings MJ, Baldwin MR, Abrams D, Jacobson SD, Meyer BJ, Balough EM, et al. Epidemiology, clinical course, and outcomes of critically ill adults with COVID-19 in New York City: a prospective cohort study. The Lancet. 2020 May 19.

[20] Argenziano MG, Bruce SL, Slater CL, Tiao JR, Baldwin MR, Barr RG, et al. Characterization and clinical course of 1000 patients with coronavirus disease 2019 in New York: retrospective case series. bmj. 2020 May 29;369.

[21] Magleby R, Westblade LF, Trzebucki A, Simon MS, Rajan M, Park J, et al. Impact of SARS-CoV-2 viral load on risk of intubation and mortality among hospitalized patients with coronavirus disease 2019. Clinical infectious diseases. 2020 Jun 30.

[22] Amirian ES. Potential fecal transmission of SARS-CoV-2: current evidence and implications for public health. International Journal of Infectious Diseases. 2020 Apr 23.

[23] Argyropoulos KV, Serrano A, Hu J, Black M, Feng X, Shen G, et al. Association of initial viral load in severe acute respiratory syndrome coronavirus 2 (SARS-CoV-2) patients with outcome and symptoms. The American journal of pathology. 2020 Sep 1;190(9):1881-7.

[24] Arons MM, Hatfield KM, Reddy SC, Kimball A, James A, Jacobs JR, et al. Presymptomatic SARS-CoV2 infections and transmission in a skilled nursing facility. New England journal of medicine. 2020 Apr 24.

[25] Ison MG, Wolfe C, Boucher HW. Emergency Use Authorization of Remdesivir: The Need for a Transparent Distribution Process. JAMA. 2020 May 14.

\section{Figures}




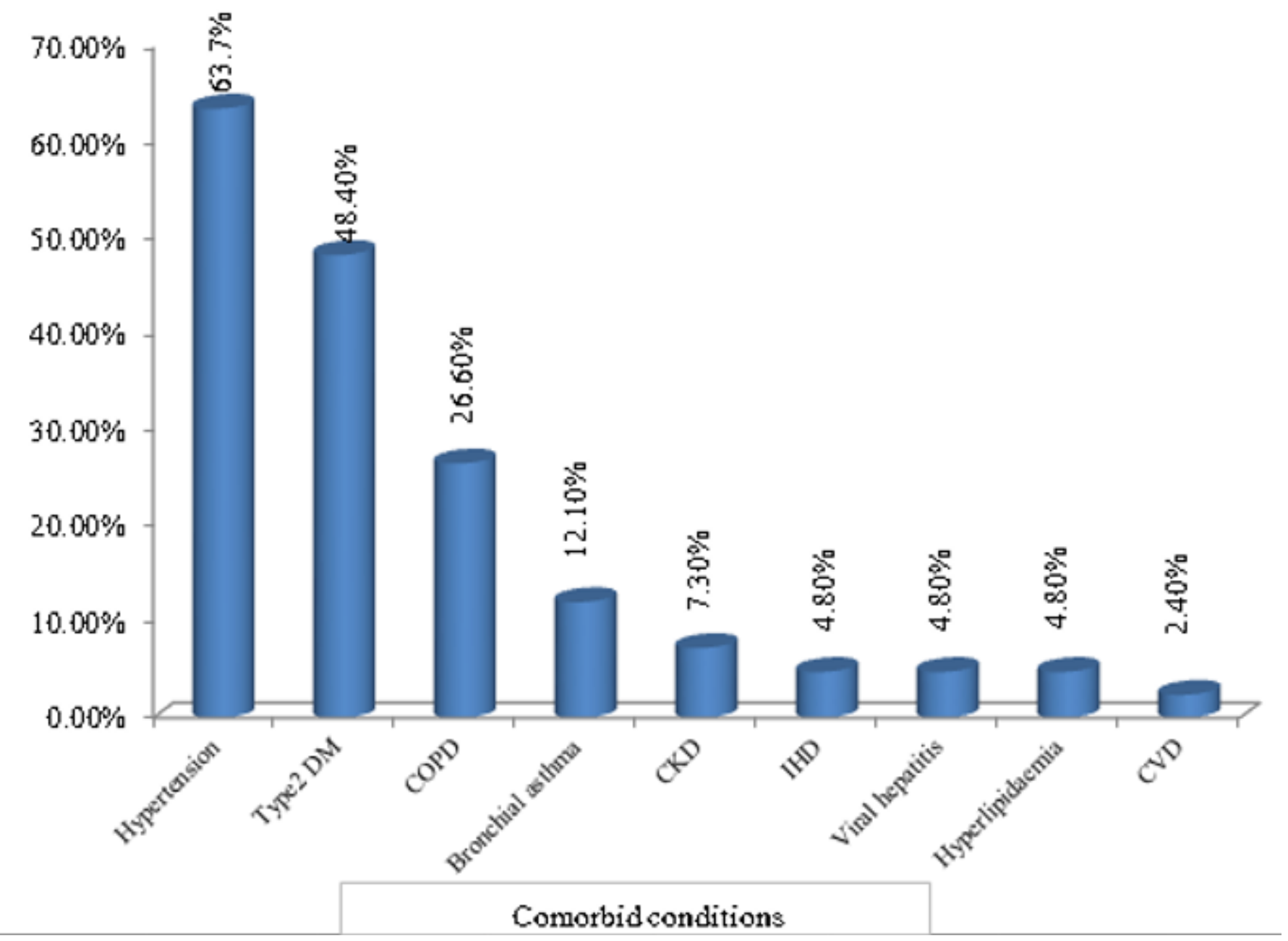

Figure 1

Percentage distribution of the patient's comorbid conditions 